\title{
Production in vitro of mouse early pregnancy factor and purification to homogeneity
}

\author{
Alice C. Cavanagh \\ Department of Surgery, University of Queensland, Princess Alexandra Hospital, Brisbane, \\ Queensland 4102, Australia
}

\begin{abstract}
Summary. Early pregnancy factor (EPF) has been produced in vitro by culture of oestrous mouse oviducts and ovaries in RPMI, with the addition of prolactin and mouse embryo culture medium. The pooled harvested medium was then subjected to immunoabsorption, electrofocussing and gel filtration. A fraction was isolated with $\mathrm{pI}$ 6.83 and molecular weight 21000 which was responsible for $90 \%$ of the recovered biological activity. It appeared to be homogeneous when analysed by highperformance gel-permeation chromatography. SDS treatment showed that the molecule could be split into 3 peptides of molecular weights 10500,7200 and 3400 , the first having activity equivalent to the EPF component EPF-A from the oviduct, while the last two combined to give activity corresponding with the ovarian component EPF-B.
\end{abstract}

\section{Introduction}

Since early pregnancy factor (EPF) was first described by Morton, Hegh \& Clunie in 1976, our understanding of its properties has increased considerably. Studies of some of the characteristics of mouse (Clarke, Morton \& Clunie, 1978), sheep (Clarke, Morton, Rolfe \& Clunie, 1980), human (Rolfe, Morton \& Clarke, 1983a) and pig (Morton, Morton \& Ellendorff, 1983) EPF have been reported, but further investigation has been hampered by lack of purified material.

Mouse EPF was chosen for this investigation because this species has proved useful in studies on the biological and immunological role of EPF (Morton et al., 1976, 1980; Noonan, Halliday, Morton \& Clunie, 1979; Morton, Rolfe \& Cavanagh, 1982a). Choice of the mouse, however, introduces the problem of suitable starting material for purification. To date, serum and urine have been used for the characterization of EPF, and serum for the only published report on the isolation of EPF (Wilson, McCarthy \& Clarke, 1983). The difficulties associated with either of these sources in the mouse are obvious, and an alternative was investigated, based on studies by Morton et al. (1980) on the site of production of EPF in the mouse. This work showed that EPF is produced initially in two parts, EPF-A by the oviduct during oestrus and pregnancy and EFP-B by the ovary only during pregnancy. Apart from being oestrus-dependent, control of EPF-A production is not yet understood, but it is known that the ovary of non-pregnant animals can be stimulated to produce EPF-B by prolactin and an 'ovum factor' (Morton et al., 1982a; Cavanagh, Morton, Rolfe \& Gidley-Baird, 1982). The oviducts and ovaries of oestrous mice were therefore cultured with prolactin and 'ovum factor' and EPF was isolated from the proteins released into the medium. The purification procedures undertaken and a preliminary analysis of the end product are the subject of this report. 


\section{Materials and Methods}

\section{Animals}

Outbred Quackenbush mice, $8-12$ weeks old, were used throughout. Vaginal smears were used to select females in dioestrus (Rugh, 1968), while ovulntion was induced in other animals by i.p. injection of 10 i.u. each of PMSG (Folligon: Intervet, Melbourne, Australia) and hCG (Pregnyl; Organon, Morden, U.K.) given approximately $48 \mathrm{~h}$ apart (Edwards \& Gates, 1959).

\section{Assay}

EPF was assayed by the rosette inhibition test (Morton et al., 1974; Rolfe et al., 1984), using male mouse spleen cells, rabbit anti-mouse lymphocyte serum and human red blood cells. Results were recorded as the rosette inhibition titre (RIT); this titre is the reciprocal of the highest dilution of anti-lymphocyte serum in which the number of rosettes formed between spleen cells and red blood cells is less than $75 \%$ of the number formed without anti-lymphocyte serum. The RIT is expressed as the logarithm (to base 2) of the reciprocal dilution of anti-lymphocyte serum $\times 10^{-3}$. All tests were performed in parallel with a positive (pregnancy serum or EPF-containing culture medium) and negative (non-pregnancy serum or Hank's balanced salt solution) control. A single batch of anti-lymphocyte serum was used throughout the study.

Except when minimum detection units (MDU) were being determined (see 'Results'), all samples were diluted from $5 \times 10^{2}$ to $5 \times 10^{3}$ times with $0.05 \mathrm{M}$-sodium phosphate buffer $\mathrm{pH} 7 \cdot 4$ containing $0.9 \%(\mathrm{w} / \mathrm{v})$ sodium chloride (PBS) before assay. In addition, since even trace amounts of detergents and sodium azide have been found to interfere with the assay (Morton, Tinneberg, Rolfe, Wolfe \& Mettler, 1982b), samples containing these substances were dialysed againt PBS after dilution (Visking dialysis tubing, $\mathbf{M}_{\mathrm{r}}$ cut-off $5 \times 10^{3}$; Union Carbide, IL, U.S.A.). The peptides produced by sodium dodecyl sulphate (SDS; BDH, Poole, U.K.) were exchanged into PBS by filtration on small columns of Sephadex G-15 (Pharmacia, Uppsala, Sweden).

\section{Organ culture}

RPMI 1640 tissue culture medium (Flow Laboratories, Irvine, U.K.) containing penicillin (100 units/ml; Glaxo, Melbourne, Australia), streptomycin $(100 \mu \mathrm{g} / \mathrm{ml}$; Glaxo) and fungizone $(2.5$ $\mu \mathrm{g} / \mathrm{ml}$; Flow Laboratories) was used throughout.

Production of EPF. Batches of 40 mice were superovulated and ovaries and oviducts were removed within $20 \mathrm{~h}$ after hCG injection. The organs were washed in culture medium and those from pairs of mice placed in Petri dishes; $7 \mathrm{ml} \mathrm{RPMI}$ containing $2 \mu \mathrm{g}$ rat prolactin (PRL-3; NIH, Bethesda, U.S.A.) and $50 \mu \mathrm{l}$ mouse embryo culture medium (harvested from about 402 -cell to morula-stage embryos per $\mathrm{ml}$ medium; Cavanagh et al., 1982) were added to each dish. The cultures were maintained in an humidified atmosphere of $5 \% \mathrm{CO}_{2}$ in air at $37^{\circ} \mathrm{C}$.

Culture medium was removed at 2-day intervals and replaced by fresh medium with the same additives. At each harvest, medium was pooled and aprotinin (Trasylol; Bayer, Leverkusen, West Germany) and sodium azide were added to final concentration of $200 \mathrm{ki} . \mathrm{u} . / \mathrm{ml}$ and $0.02 \%$ respectively. The medium was then filter-sterilized and stored at $4^{\circ} \mathrm{C}$. This temperature is recommended since $\mathrm{EPF}$ is stable at $-30^{\circ} \mathrm{C}$ but appears to be sensitive to more than one freezethaw cycle. After the third harvest, tissue was discarded.

Blank culture. Ovaries and oviducts from 45 dioestrous mice were cultured as for EPF production except that prolactin and embryo culture medium were not added until after the medium had been harvested.

\section{Production of antiserum}

EPF culture medium $\left(40^{-} \mathrm{ml}\right)$ was dialysed (Visking dialysis tubing, $\mathbf{M}_{\mathrm{r}}$ cut-off $5 \times 10^{3}$ ) against $0.9 \%(\mathrm{w} / \mathrm{v}) \mathrm{NaCl}$ and concentrated to $4 \mathrm{ml}$ in an ultrafiltration cell (8MC; Amicon, MA, U.S.A.) 
using a membrane with an $\mathrm{M}_{\mathrm{r}}$ cut-off of $10^{4}$ (YM-10; Amicon). It was then filter-sterilized and emulsified with $6 \mathrm{ml}$ Freund's complete adjuvant (CSL, Melbourne, Australia). This was injected into a goat at multiple subcutaneous sites at monthly intervals for 4 months. Serum was then obtained and the IgG fraction prepared by sodium sulphate precipitation (Chard, 1978). The IgG was reconstituted to the original serum volume with $0.9 \%(w / v) ~ \mathrm{NaCl}$ containing $0.02 \%$ sodium azide and stored at $4^{\circ} \mathrm{C}$. References to anti-EPF are to this IgG fraction.

\section{Preparation of immunoabsorbent}

Blank culture medium $(450 \mathrm{ml})$ was bound to $15 \mathrm{ml} \mathrm{CNBr-Sepharose} \mathrm{(Pharmacia)} \mathrm{(Axen,}$ Porath \& Ernback, 1967) and the gel was equilibrated with PBS containing 0.5\% Tween 20 (PBS$\mathrm{T})$. The gel was mixed with $15 \mathrm{ml}$ anti-EPF $\mathrm{IgG}(10 \mathrm{mg}$ protein $/ \mathrm{ml})$ for $1 \mathrm{~h}$ at room temperature, then centrifuged and the supernatant concentrated to the original serum volume and stored at $4^{\circ} \mathrm{C}$. Another $15 \mathrm{ml}$ batch of anti-EPF IgG was absorbed after regeneration of the gel by washing with glycine- $\mathrm{HCl}$ buffer $\mathrm{pH} 2.2$ followed by PBS-T. Absorbed anti-EPF IgG $(30 \mathrm{ml})$ was then bound to CNBr-Sepharose for use as an immunoabsorbent.

The capacity of the absorbed anti-EPF IgG to neutralize EPF activity was tested as follows. A sample was dialysed againt PBS (see 'Methods' above) and various dilutions were prepared with PBS. A $0 \cdot 1 \mathrm{ml}$ sample of each dilution was incubated with culture medium containing 50 MDU EPF ( $\sim 1 \mathrm{ng}$, see 'Results') for $1 \mathrm{~h}$ at $37^{\circ} \mathrm{C}$. The incubate was then tested for EPF.

\section{Purification of EPF}

Immunoabsorption. EPF culture medium harvests 1,2 and 3 were pooled, Tween 20 was added to a final concentration of $0.5 \%$ and then the immunoabsorbent was added. The slurry was mixed gently at $4^{\circ} \mathrm{C}$ overnight then centrifuged; the supernatant was discarded. The gel was washed with 10 volumes $0.05 \mathrm{M}$-sodium phosphate buffer $\mathrm{pH} 7.4$ containing $0.5 \mathrm{M}$-sodium chloride and $0.5 \%$ Tween 20 (to remove non-specifically bound proteins), followed by 2 volumes PBS-T and packed into a $25-\mathrm{mm}$ diameter column. Glycine- $\mathrm{HCl}$ buffer $\mathrm{pH} 2.2$ containing $0.5 \%$ Tween 20 was applied at $10 \mathrm{ml} / \mathrm{h}$ and $2-\mathrm{ml}$ fractions were collected into $2 \mathrm{ml} \mathrm{0.1} \mathrm{M-sodium} \mathrm{phosphate} \mathrm{buffer} \mathrm{pH} \mathrm{7.4}$. Each fraction was tested for EPF, then EPF-containing fractions were pooled and dialysed extensively against $1 \%$ glycine containing $0.5 \%$ Tween 20 .

Preparative electrofocussing. The immunoabsorbent eluate containing the EPF was incorporated into a $70 \mathrm{ml}$ horizontal bed of a granulated gel (Ultrodex; LKB, Bromma, Sweden) containing $2 \%$ ampholine pH 5-8 (LKB) and $0.5 \%$ Tween 20 , prepared according to the manufacturer's instructions. Electrofocussing was carried out at $10^{\circ} \mathrm{C}$ for $18 \mathrm{~h}$ at $8 \mathrm{~W}$ (Radola, 1974). The gel was then fractionated by application of a grid with 7-mm wide intervals. The surface $\mathrm{pH}$ of each fraction was determined, the fractions scooped out and eluted with $3 \mathrm{ml} 0.005 \mathrm{M}$-sodium phosphate buffer pH 7.4 or PBS. Each fraction was tested for EPF.

Gel filtration. The EPF profile after electrofocussing was examined by 2 procedures. (1) The $\mathrm{pH}$ 6.49 and $\mathrm{pH} 6.83$ fractions (Fractions 18 and 21 respectively; see 'Results') were eluted from the electrofocussing gel with PBS and applied separately to a Sephacryl S-300 (Pharmacia) column (16 $\times 395 \mathrm{~mm}$ ) equilibrated with the same buffer and calibrated with the Pharmacia high and low molecular weight marker kits. A 1-ml sample was applied, and 1-ml fractions were collected and tested for EPF as indicated (see 'Results'). (2) One ml of Fraction 21 eluted with PBS was applied to a Sephadex G-100 (Pharmacia) column $(16 \times 895 \mathrm{~mm})$ equilibrated with PBS and calibrated with the Pharmacia low-molecular weight marker kit; 2-ml fractions were collected and tested for EPF as indicated (see 'Results'). In addition, Fraction 21 from another electrofocussing gel was eluted with $0.005 \mathrm{M}$-sodium phosphate buffer $\mathrm{pH} 7.4$ and fractionated similarly on the Sephadex G-100 column equilibrated with sodium phosphate buffer. As a result of these studies (see 'Results'), the following protocol was adopted for the purification procedure. Fraction 21 from the electro- 
focussing gel was eluted with $3 \mathrm{ml} 0.005 \mathrm{M}$-sodium phosphate buffer $\mathrm{pH} 7.4$ and the entire volume was applied to the Sephadex G-100 column equilibrated with the same buffer. Then, 2-ml fractions were collected into polyethylene tubes (Minisorb; Nunc, Roskilde, Denmark), the EPF-containing fractions were pooled, dispensed in $1-\mathrm{ml}$ volumes and freeze-dried.

\section{High-performance liquid chromatography}

Gel permeation chromatography was performed on a TSK G3000 SW column, $7.5 \times 600 \mathrm{~mm}$ (LKB). The following proteins with molecular weights indicated were used to calibrate the column: thyroglobulin $(669000)$, ferritin $(440000)$, catalase $(232000)$, bovine serum albumin $(67000)$, ovalbumin (43000), chymotrypsinogen A (25000) and ribonuclease (13 700), all obtained from Pharmacia; insulin chain A (2333; Sigma, MO, U.S.A.); and LKB molecular weight markers based on myoglobulin (16 949) and peptides cleaved from it by cyanogen bromide $\left(\mathrm{M}_{\mathrm{r}}\right.$ values of $14404,8159,6214$ and 2512). Blue dextran 2000 and sodium azide were used to determine the void volume $\left(\mathrm{V}_{0}\right)$ and total column volume $\left(\mathrm{V}_{\mathrm{t}}\right)$ respectively. Proteins were chromatographed under non-denaturing and denaturing conditions. For the former, proteins were reconstituted and eluted in $0.1 \mathrm{M}$-sodium phosphate buffer $\mathrm{pH} 6.7$ containing $0 \cdot 1 \% 3-\{(3$-cholamidopropyl)dimethylammonio\}-1-propanesulphonate (CHAPS; Sigma) while for the latter, $0 \cdot 1 \mathrm{M}$-sodium phosphate buffer pH 6.7 containing $0.1 \%$ SDS was used. With buffer containing CHAPS, the linear fractionation range of the column was 400000 to 4000 while with buffer containing SDS, in which proteins unfold and hence have a larger radius, it was 150000 to 1000 .

A $1 \mathrm{ml}$ sample of freeze-dried EPF $(10 \mu \mathrm{g})$ was reconstituted in $100 \mu \mathrm{l}$ of each buffer and a $20 \mu \mathrm{l}$ sample was applied to the column immediately or after incubation at room temperature for 1,3 or $5 \mathrm{~h}$. The same buffer was used for reconstitution and elution. A flow rate of $0.5 \mathrm{ml} / \mathrm{min}$ was maintained and the optical density of the column effluent monitored at a wavelength of $220 \mathrm{~nm}$. When appropriate, $0.5 \mathrm{ml}$ fractions were collected and every second fraction was tested for EPF.

\section{Protein estimation}

The protein content of samples was determined by spectrophotometry at $205 \mathrm{~nm}$ (Scopes, 1974).

\section{Results}

Assay

The basis of the assay for EPF is its ability to enhance the rosette-inhibiting activity of antilymphocyte serum, i.e. incubation of spleen cells in a solution containing EPF before performing the rosette inhibition test will increase the RIT of an anti-lymphocyte serum. In this study the mean RIT obtained after incubation of spleen cells in the BSS negative control was $9 \cdot 2($ s.e. $0 \cdot 38, n=12)$ while for the non-pregnancy serum negative control it was $9 \cdot 0$ (s.e. $0 \cdot 35, n=12$ ). An RIT greater than 2 standard deviations above this value (RIT > 12) was therefore taken as positive evidence of the presence of EPF. For the positive controls, the mean RIT with culture medium containing 25 MDU EPF (approximately $0.5 \mathrm{ng}$, see below) was $25 \cdot 2$ (s.e. $0.64, n=12$ ) and with pregnancy serum it was $24 \cdot 3$ (s.e. $0 \cdot 67, n=12$ ).

The dose-response characteristics of the assay with purified EPF are shown in Text-fig. 1. From $100 \mathrm{pg} / \mathrm{ml}$ to $5 \mathrm{ng} / \mathrm{ml}$ EPF ( $20 \mathrm{pg}$ to $1 \mathrm{ng}$ ) can be detected by the assay with an approximately linear response in the range $100 \mathrm{pg} / \mathrm{ml}$ to $1 \mathrm{ng} / \mathrm{ml}$. Above this amount, the response plateaus, then falls off at concentrations $>5 \mathrm{ng} / \mathrm{ml}$. Samples suspected of containing high concentrations of EPF (e.g. column fractions) therefore need to be suitably diluted before assay. The reason for this loss of responsiveness is presently unknown; it may reflect aggregation of EPF above a certain concentration, with consequent loss of biological activity. It is encountered only with the comparatively high 


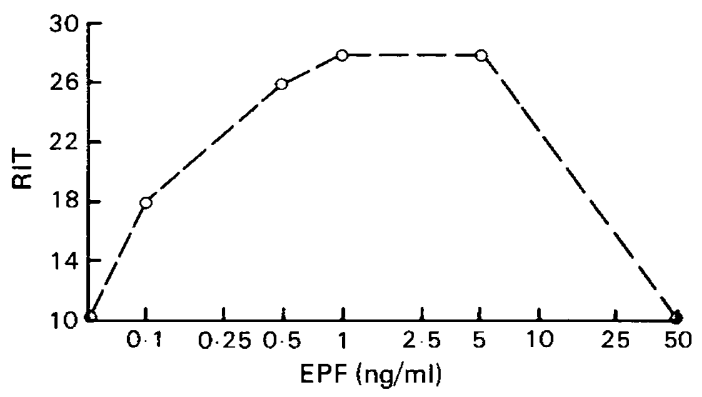

Text-fig. 1. Rosette inhibition titres (RIT) obtained with lymphocytes preincubated in $0 \cdot 2 \mathrm{ml}$ of various concentrations of purified EPF. Results are the mean of duplicate estimations; RIT values $>12$ indicate a positive result.

concentrations of EPF possible through use of purified material; such concentrations are not present in serum.

To use the assay as a roughly quantitative measure of EPF, the highest dilution of sample to give activity in the assay was determined and an MDU defined as the amount of EPF in $0.2 \mathrm{ml}$ (the volume placed on the cells in the assay) of this dilution. As an example, the final purified product was active to a dilution of 1 in $10^{5}$, hence it contained $5 \times 10^{5} \mathrm{MDU} / \mathrm{ml}$. Since it was estimated that this material contained $\sim 10 \mu \mathrm{g} / \mathrm{ml}$ protein, $1 \mathrm{MDU}$ is therefore equivalent to $20 \mathrm{pg}$ EPF. This must be regarded as an approximation, as only 50-fold dilutions were used in determining an MDU. Moreover, this extensive dilution procedure was used only to monitor the overall recovery of EPF throughout the purification (see Table 1). For the individual fractions at each step (see Text-figs 2 $\& 3$.), a single dilution judged sufficient to detect the most concentrated fraction was used; hence these may not provide quantitative data on EPF activity.

\section{EPF production in culture}

After each harvest, the pool was sampled before addition of aprotinin and sodium azide and various dilutions were tested for EPF. Harvest 1 contained $5 \times 10^{4} \mathrm{MDU} / \mathrm{ml}$, harvest $2,5 \times 10^{3}$ $\mathrm{MDU} / \mathrm{ml}$ and harvest $3,5 \times 10^{2} \mathrm{MDU} / \mathrm{ml}$. Because of this diminishing production, culture of the organs after the 3 rd harvest was not considered worthwhile.

\section{Antiserum to EPF}

A $0.1 \mathrm{ml}$ volume of a 1 in 2100 dilution of absorbed anti-EPF IgG reduced the RIT of a culture medium sample containing $1 \mathrm{ng}$ EPF from 28 to 10 ; the RIT was reduced to 16 when a 1 in 3500 dilution was used. It was therefore estimated that $1 \mathrm{ml}$ of the absorbed anti-EPF IgG was capable of neutralizing $20 \mu \mathrm{g}$ EPF and that the prepared immunoabsorbent had the theoretical capacity to absorb $600 \mu \mathrm{g}$ EPF. The maximum amount that was applied to the immunoabsorbent is approximately $200 \mu \mathrm{g}$, all of which was absorbed.

\section{Purification of EPF}

Approximately $400 \mathrm{ml}$ EPF culture medium was produced from a batch of 40 mice and processed immediately. The purification scheme illustrated in Table 1 consisted of 3 steps, immunoabsorption, electrofocussing and gel filtration, each of which is considered below.

Immunoabsorption. As shown in Text-fig. 2(a), at low pH EPF was eluted from the immunoabsorbent as a sharp peak coinciding with the protein peak. The eluate requires further treatment since the immunoabsorbent is not monospecific. Moreover, any free EPF components (EPF-A and EPF-B; Morton et al., 1980) present in the starting material could bind even to a specific absorbent. 
Table 1. Purification of mouse EPF

\begin{tabular}{lccccc}
\hline & Volume (ml) & EPF (MDU) & Recovery EPF (\%) & Protein $(\mu \mathrm{g})$ & $\begin{array}{c}\text { Purification } \\
\text { factor }\end{array}$ \\
\hline EPF culture medium & 400 & $10^{7}$ & 100 & 246400 & 1 \\
Immunoabsorbent eluate & 16 & $9 \times 10^{6}$ & 90 & 1321 & 167 \\
Electrofocussing eluate (Fraction 21) & 3 & $6 \times 10^{6}$ & 60 & 435 & 340 \\
G-100 fraction & 10 & $5 \times 10^{6}$ & 50 & 100 & 2217 \\
\hline
\end{tabular}

Preparative electrofocussing. The $\mathrm{pH}$ gradient and EPF profile of the gel fractions are shown in Text-fig. 2(b). EPF appeared in 2 sharp bands at pH 6.49 (Fraction 18) and 6.83 (Fraction 21). As a result of a preliminary analysis of the 2 fractions (described below), Fraction 21 was eluted with $0.005 \mathrm{M}$-sodium phosphate buffer $\mathrm{pH} 7.4$ and gel-filtered in this buffer.

Gel filtration. The elution profile of EPF on Sephadex G-100 equilibrated with 0.005 M-sodium phosphate buffer $\mathrm{pH} 7.4$ is shown in Text-fig. 2(c). EPF appeared as a sharp peak at an apparent $M_{r}$ of 20000 . Protein was monitored at the more sensitive wavelength of $214 \mathrm{~nm}$ to detect the peak corresponding with this activity. The 5 fractions eluting between 114 and $124 \mathrm{ml}$ were then pooled and freeze-dried.
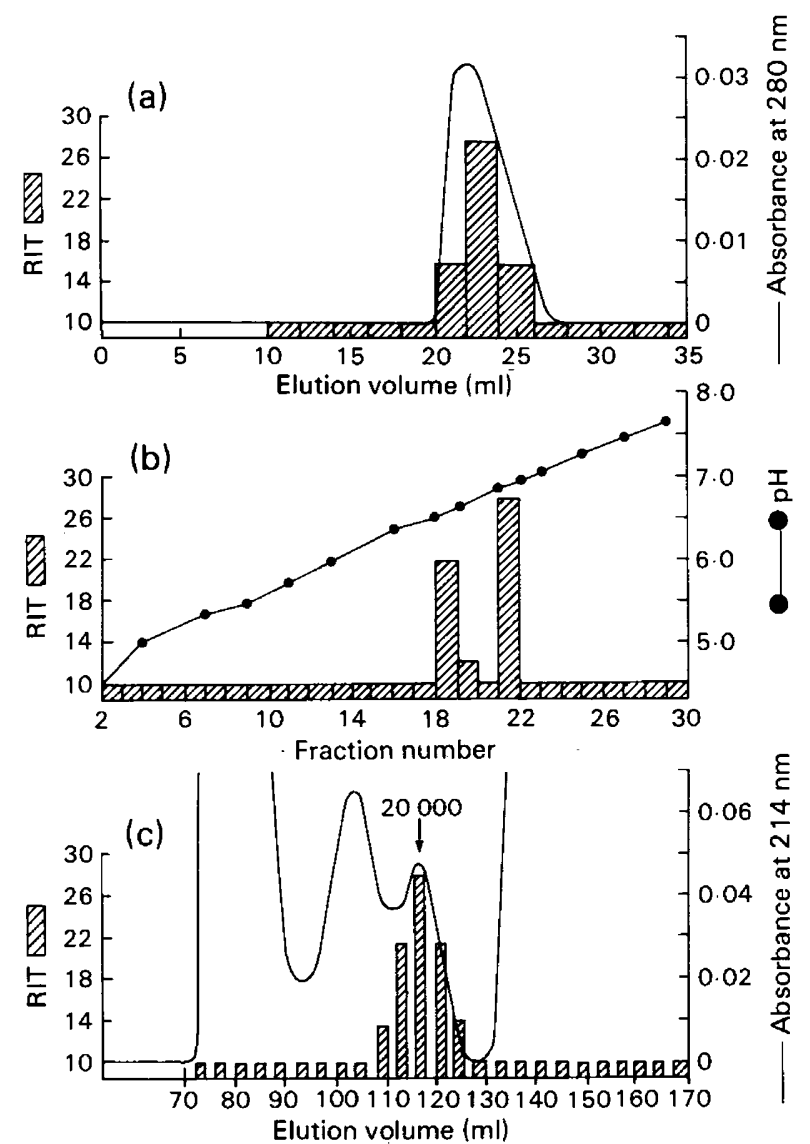

Text-fig. 2. The purification of EPF from $400 \mathrm{ml}$ EPF culture medium showing (a) the elution of EPF and protein from the immunoabsorbent; (b) electrofocussing of EPF from (a) (Fractions 18-26 ml), with the pH gradient of the gel illustrated; and (c) the elution profile of EPF and protein after gel filtration of Fraction 21 from (b) on Sephadex G-100. EPF is expressed as RIT, with values $>12$ indicating a positive result. Protein is expressed as absorbance monitored continuously at the wavelength indicated. 
Analysis of electrofocussing fractions

The elution profiles of Fractions 18 and 21 on Sephacryl S-300 equilibrated with PBS are shown in Text-fig. 3(a). A multimolecular weight pattern typical of EPF (Clarke et al., 1978, 1980; Morton et al., 1983; Rolfe et al., 1983a) was observed with both fractions, but the 500000 and 240000 forms were absent from Fraction 21. These larger forms have been shown to be due to the association of EPF with a carrier molecule; upon removal of the carrier, EPF appears in the smaller molecular weight forms found in Fraction 21 (Clarke et al., 1980; Rolfe et al., 1983a).

Fraction 21 was further analysed by application to Sephadex G-100 in both PBS and 0.005 Msodium phosphate buffer $\mathrm{pH} 7 \cdot 4$. The apparently complex molecular weight pattern observed with PBS was reduced to a single peak of 20000 at low ionic strength (Text-fig. 3b). As a result of these studies, Fraction 21 was eluted in $0.005 \mathrm{M}$-sodium phosphate buffer $\mathrm{pH} 7.4$ and applied to Sephadex G-100 equilibrated with this buffer as a final purification step (see 'Methods'). After freeze-drying, the 20000 fraction off the column was analysed by HPLC.
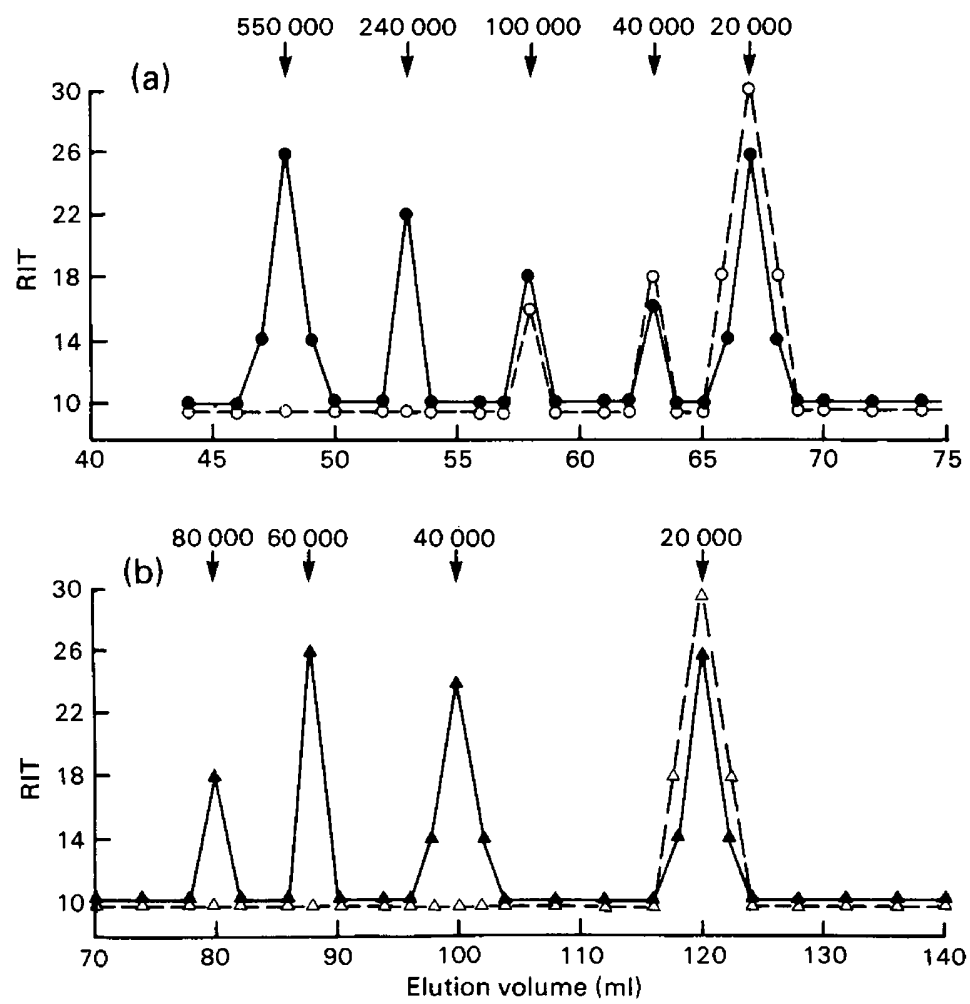

Text-fig. 3. Gel filtration profiles of EPF in Fractions 18 and 21 from an electrofocussing gel (see Text-fig. 2b); (a) Fractions $18\left(O_{-}\right)$and $21\left(\mathrm{O}_{--} \mathrm{O}\right)$ after application to Sephacryl S300 with PBS as the elution buffer; (b) Fraction 21 after application to Sephadex G-100 and elution with PBS $(\boldsymbol{\Delta}-\mathbf{\Delta})$ and $0.005 \mathrm{M}$-sodium phosphate buffer $\mathrm{pH} 7.4(\triangle---\triangle)$. EPF is expressed as the RIT; values $>12$ indicate a positive result.

\section{$H P L C$}

In preliminary gel permeation chromatography experiments in which PBS was used as the elution buffer, the protein peak had an elution volume greater than $V_{t}$, indicating interaction with the column (data not shown). The silica-based matrices used in HPLC gel permeation columns exhibit cation exchange, anion exclusion and hydrophobic binding effects with some proteins (Pfannkoch, Lu \& Regnier, 1980). In this case it was considered that hydrophobic rather than ionic 
effects were responsible for the retardation since changes of sodium chloride concentration ( 0 to $1 \mathrm{M})$ in the elution buffer failed to alter the elution pattern of the protein. Addition of a detergent to the elution buffer should be able to overcome hydrophobic interactions, and because of the tendency of EPF to self-associate (see 'Results' above), the disaggregating but non-denaturing, zwitterionic detergent CHAPS (Hjelmeland, 1980) was chosen.

The elution pattern of an EPF sample, applied to the column immediately after reconstitution in $0.1 \mathrm{M}$-sodium phosphate buffer $\mathrm{pH} 6.7$ containing $0.1 \% \mathrm{CHAPS}$ and eluted in the same buffer, is shown in Text-fig. 4(a). A single protein peak coincident with rosette inhibiting activity eluted at the void volume $\left(M_{r}>400000\right)$. Since the preparation was a 20000 fraction off a gel filtration column, it was concluded that the peak represented an aggregated form of EPF. This was confirmed, as shown in Text-figs 4(b) and (c), by preincubation of the sample in the buffer for various times before column application. After $1 \mathrm{~h}$, some protein still eluted at $\mathrm{V}_{\mathrm{t}}$, but the major peak eluted with an apparent $M_{r}$ of 21000 . Smaller peaks were seen at 40000 and 62000 (Text-fig. $4 \mathrm{~b}$ ). Incubation for $3 \mathrm{~h}$ resulted in virtually all the protein appearing in the 21000 form (Text-fig. $4 c)$. Rosette inhibiting activity paralleled the protein peaks. Since larger or smaller amounts of EPF eluted at the same positions when treated similarly (data not shown), it was considered that the buffer had overcome column interaction effects and that these elution profiles reflected true gel permeation fractionation. Text-figure 4 also shows the elution pattern of prolactin under similar conditions. This is included because relatively large amounts of prolactin were added to the original cultures and could have been a contaminant of the preparation as it exhibits some properties which are similar to those of EPF. The monomeric form of prolactin eluted very close to EPF and a dimer was observed, but a large aggregate which was progressively converted to a smaller form did not appear.

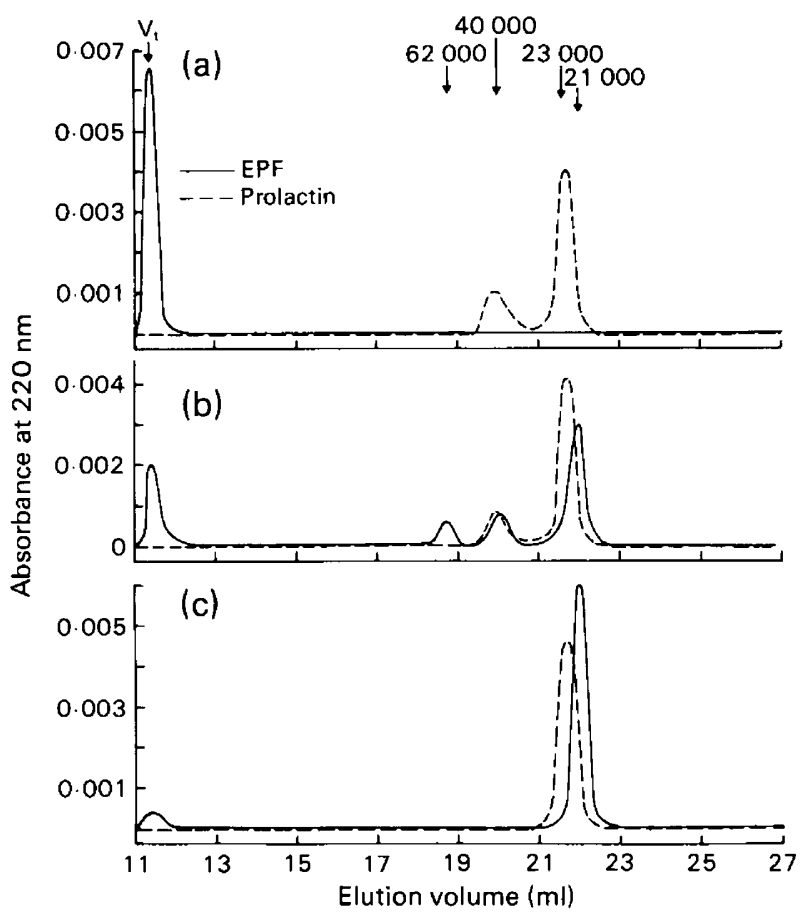

Text-fig. 4. Protein profiles at $A_{220}$ after application of EPF and prolactin to a G3000 SW column. Freeze-dried samples were reconstituted in $0.1 \mathrm{M}$-sodium phosphate buffer $\mathrm{pH} 6.7$ containing $0.1 \%$ CHAPS applied to the column (a) immediately, or after (b) $1 \mathrm{~h}$ or (c) $3 \mathrm{~h}$ incubation. The same buffer was used for elution. The apparent molecular weights of the peaks are indicated. 
Gel permeation chromatography was also used in a preliminary investigation of the subunit structure of EPF after treatment with SDS. The resolution of this technique is at least comparable with SDS-polyacrylamide gel electrophoresis and is reported to be more reproducible (Takagi, Takeda \& Okuno, 1981). A particular advantage of the method is the easy recovery of sample. After reconstitution of an EPF sample in $0.1 \mathrm{M}$-sodium phosphate buffer $\mathrm{pH} 6.7$ containing $0.1 \%$ SDS followed by immediate application to the column and elution in the same buffer, the protein profile illustrated in Text-fig. 5(a) was observed. A small peak was seen at the void volume $\left(M_{r}>150000\right)$ along with 3 larger peaks corresponding to $M_{r} 10500,7200$ and 3400 (peaks 1, 2 and 3 respectively). Rosette inhibiting activity was associated only with the peak at the void volume. This peak and its associated rosette inhibiting activity disappeared when samples were incubated in the buffer for $3 \mathrm{~h}$ before column application, but the 3 other peaks remained (Text-fig. 5b). Since activity could be recovered by combination of all 3 peaks, but not by combination of any 2 , it was concluded that SDS splits the protein into 3 peptides, all of which are required for activity. In addition, since the elution pattern was not altered by reduction of the protein with dithiothreitol (data not shown), it was concluded that disulphide bonds are not involved in interchain linkage. This behaviour clearly distinguishes EPF from prolactin which, as Text-fig. 5 illustrates, was not dissociated into a number of components.

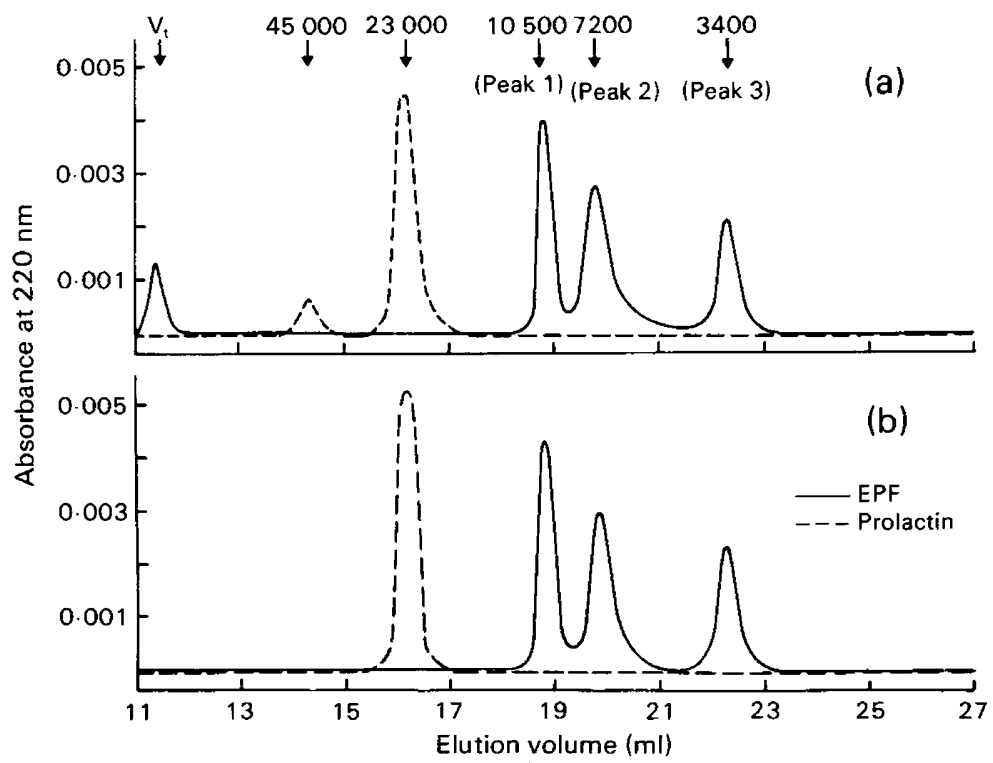

Text-fig. 5. Protein profiles at $A_{220}$ after application of EPF and prolactin to a G3000 SW column. Freeze-dried samples were reconstituted in $0.1 \mathrm{M}$-sodium phosphate buffer $\mathrm{pH} 6.7$ containing $0.1 \%$ SDS applied to the column (a) immediately or (b) after $3 \mathrm{~h}$ incubation. The same buffer was used for elution. The apparent molecular weights of the peaks are indicated.

The relationship of the 3 peptides with the components previously designated EPF-A and EPFB (Morton et al., 1980; Clarke et al., 1980) was next investigated. Table 2 shows results obtained after various combinations of peaks 1, 2 and 3 were mixed with EPF-A or EPF-B (Morton et al., 1980; Cavanagh et al., 1982). Activity was obtained only by combination of peak 1 with EPF-B and peaks 2 and 3 with EPF-A. 
Table 2. Rosette inhibition titre (RIT)* after combination of SDS-produced subunits (peaks 1, 2 and 3) and oviduct (EPF-A) and ovary (EPF-B) components

\begin{tabular}{lcccc}
\hline & BSS & EPF-A & EPF-B & EPF-A + EPF-B \\
\hline BSS & 10 & 10 & 10 & 22 \\
Peak 1 & 10 & 10 & 20 & - \\
Peak 2 & 10 & 10 & 10 & - \\
Peak 3 & 10 & 10 & 10 & - \\
Peaks 1 +2 & 10 & - & - & - \\
Peaks 1 +3 & 10 & 18 & 10 & - \\
Peaks 2 +3 & 10 & - & - & - \\
Peaks 1 $+2+3$ & 26 & & -
\end{tabular}

*Values are the means of duplicate assays. An RIT > 12 is evidence of the presence of EPF.

\section{Discussion}

The procedure for isolation of mouse EPF described above has two key features, the production of EPF in vitro and the use of an immunoabsorbent as the first step in purification. The in-vitro culture of oviducts from oestrous mice and ovaries in the presence of prolactin and 'ovum factor' results in the production of EPF in a form that is both readily obtainable and accompanied by a minimum of extraneous proteins. In addition a 'blank' or control culture may be produced from organs of dioestrous mice, with the same contents excepting EPF and oestrus-specific products. Therefore, a relatively specific antiserum for use in purification can be prepared by absorbing an antiserum to crude starting material with 'blank' medium.

Immunoabsorption as an initial step offers several benefits. A comparatively large volume of starting material can be reduced to a small volume with a minimum of handling and approximately 200-fold purification; no detectable EPF remains in the medium after mixing with the immunoabsorbent, and virtually all the starting EPF is recovered in the eluate. Nevertheless, another type of affinity matrix may be substituted. One which has been investigated in this laboratory is heparinSepharose (available from Pharmacia) to which EPF binds and may be eluted by application of at least $1 \mathrm{M}$-sodium chloride (unpublished data). This may prove useful to people who do not have facilities to raise antisera.

The two remaining steps in the purification scheme, in keeping with the first, are both simple and readily scaled-up. Approximately $100 \mathrm{ml}$ material containing $10 \mathrm{mg} / \mathrm{ml}$ protein can be incorporated into the electrofocussing gel without diminishing the excellent resolution of the technique (Radola, 1974). In the case of EPF, one interesting finding is its separation into 2 bands, one in apparent association with its carrier. This explanation for the 2 bands is only tentative and there may be other differences between them. Until this is better understood, the band without carrier was selected for further purification. The final gel filtration step introduces a third criterion of separation, molecular size. It provides a gentle means of removing the large amount of small material introduced by the electrofocussing step, namely ampholines, glycine and Tween, as well as larger proteins. All the detectable rosette inhibiting activity of the starting material resides in the 20000 fraction produced by this step, with the exception of the second band on the electrofocussing gel. Since the former accounts for $50 \%$ of starting activity and the latter $10 \%$, a non-specific loss of $40 \%$ has occurred throughout the preparation.

Some preliminary characterization of the material isolated by these procedures has been undertaken using high-performance gel-permeation chromatography. With a non-denaturing buffer, EPF elutes as a single protein peak accounting for virtually all the activity of the sample. The isolated material therefore appears to be homogeneous. As discussed in the 'Results', the size of the molecule indicates that it is an oligomer of EPF which, while stable, can be converted to smaller forms by pretreatment with the disaggregating agent CHAPS. Even after lengthy treatment with CHAPS, the smallest form observed has a molecular weight of 21000 and this molecule exhibits 
rosette inhibiting activity. Taken together with the studies on Sephadex G-100 in physiological and low ionic strength buffers, this indicates that the monomeric form of the molecule is approximately 21000 . The fact that addition of a detergent or reduction in ionic strength can eliminate the oligomeric forms suggests that they are the result of hydrophobic interactions. The molecule can be further reduced in size by a denaturant (SDS) but the 3 peptides produced lack activity. This can be recovered by combination of the three. EPF therefore appears to consist of 3 subunits which have been related to EPF-A and EPF-B by equating activities; the 10500 peptide appears to correspond to EPF-A from the oviduct while the 7200 and 3400 peptides together represent EPF-B from the ovary. This, however, requires confirmation with material isolated from each of these sources.

Although the resolution of the HPLC analysis is potentially excellent (Alfredson, Wehr, Tallman \& Klink, 1982), it separates proteins on the same basis as one technique used in the original preparation, namely molecular size. Hence it may fail to reveal an impurity(s) with similar size to EPF. However, unless the impurity(s) exhibits exactly the same behaviour as EPF in eluting initially as a large aggregate which is slowly reduced to its monomeric form, one would expect to see the impurity(s) at least under the conditions illustrated in Text-fig. 4(a), yet no protein with molecular weight 21000 appears. While freeze-dried prolactin did not behave in the same way as EPF (Text-fig. 4), prolactin can aggregate (Liscia, Alhadi \& Vonderhaar, 1982); however, any possibility that prolactin has co-purified with EPF is clearly ruled out by the SDS studies illustrated in Text-fig. 5.

Mouse EPF from oviducts and ovaries was selected for purification for the reasons given in the 'Introduction' but this may represent only 1 form of EPF. Morton et al. (1982a) presented evidence for 2 sources of production of EPF in the mouse, the maternal source described above, operating from fertilization until Day 6 of pregnancy, and an embryonic source developing from Day 4 of pregnancy and persisting until EPF production ceases at about Day 15. Morton et al. (1982a) also noted the production of EPF by sheep placentae in culture and Clarke \& Wilson (1982) have extracted EPF from sheep placentae. Wilson et al. (1983) reported the isolation of EPF from the serum of pregnant ewes and the stage of gestation (3-8 weeks) suggests that it is placental EPF, in contrast to maternal EPF as studied here. Although subunits have not been detected in placental EPF (Wilson et al., 1983), preliminary observations indicate that isolated maternal and placental EPF have a similar monomeric size and immunological cross-reactivity (unpublished observation).

The procedures for production and isolation of EPF discussed above provide only a modest yield of material upon which a limited analysis has been performed. Nevertheless, this represents a major advance in our knowledge of EPF; with the accumulation of more material, the differences between maternal and placental EPF can be explored and the nature of the EPF from testicular tumours (Rolfe, Morton, Cavanagh \& Gardiner, 1983b) can be investigated.

I thank the NIH for the gift of rat prolactin, and Ms K. Still for excellent typing of the manuscript.

\section{References}

Alfredson, T. V., Wehr, C.T., Tallman, L. \& Klink, F. (1982) Evaluation of new microparticulate packings for aqueous steric exclusion chromatography. $J$. Liquid Chromatog. 5, 489-524.

Axen, R., Porath, J. \& Emback, S. (1967) Chemical coupling of peptides and proteins to polysaccharides by means of cyanogen halides. Nature, Lond. 214, 1302-1304.

Cavanagh, A.C., Morton, H., Rolfe, B.E. \& Gidley-Baird, A.A. (1982) Ovum factor: a first signal of pregnancy? Am. J. Reprod. Immun. 2, 97-101.

Chard, T. (1978) An introduction to radioimmunoassay and related techniques. In Laboratory Techniques in Biochemistry and Molecular Biology, pp. 229-518. Eds T. S. Work \& E. Work. North Holland Publishing Company, Amsterdam.

Clarke, F. \& Wilson, S. (1982) Biochemistry of early pregnancy factor. In Pregnancy Proteins, pp. 407-412. Eds G. Grudzinskas, B. Teisner \& M. Seppala. Academic Press, Sydney.

Clarke, F.M., Morton, H. \& Clunie, G.J.A. (1978) Detection and separation of two serum factors responsible for depression of lymphocyte activity in pregnancy. Clin. exp. Immun. 32, 318-323. 
Clarke, F.M., Morton, H., Rolfe, B.E. \& Clunie, G.J.A. (1980) Partial characterisation of early pregnancy factor in the sheep. J. Reprod. Immun. 2, 151-162.

Edwards, R.G. \& Gates, A.H. (1959) Timing of the stages of the maturation divisions, ovulation, fertilisation and the first cleavage of adult mice treated with gonadotrophins. J. Endocr. 18, 292-304.

Hjelmeland, L.M. (1980) A nondenaturing zwitterionic detergent for membrane biochemistry: design and synthesis. Proc, natn. Acad. Sci. U.S.A. 77, 63686370 .

Liscia, D.S., Alhadi, T. \& Vonderhaar, B.K. (1982) Solubilization of active prolactin receptors by a nondenaturing zwitterionic detergent. J. biol. Chem. 257, 9401-9405.

Morton, H., Hegh, V. \& Clunie, G.J.A. (1974) Immunosuppression detected in pregnant mice by rosette inhibition test. Nature, Lond. 249, 459-460.

Morton, H., Hegh, V. \& Clunie, G.J.A. (1976) Studies of the rosette inhibition test in pregnant mice : evidence of immunosuppression? Proc. R. Soc. B 193, 413419.

Morton, H., Rolfe, B.E., McNeill, L., Clarke, P., Clarke, F.M. \& Clunie, G.J.A. (1980) Early pregnancy factor : tissues involved in its production in the mouse. $J$. Reprod. Immun. 2, 73-82.

Morton, H., Rolfe, B.E. \& Cavanagh, A.C. (1982a) Early pregnancy factor: biology and clinical significance. In Pregnancy Proteins, pp. 391-405. Eds. G. Grudzinskas, B. Teisner \& M. Seppala. Academic Press, Sydney.

Morton, H., Tinneberg, H.-R., Rolfe, B., Wolfe, M. \& Mettler, L. (1982b) Rosette inhibition test: a multicentre investigation of early pregnancy factor in humans. J. Reprod. Immun. 4, 251-261.

Morton, H., Morton, D.J. \& Ellendorff, F. (1983) The appearance and characteristics of early pregnancy factor in the pig. J. Reprod. Fert. 69, 437-446.
Noonan, F.P., Halliday, W.J., Morton, H. \& Clunie, G.J.A. (1979) Early pregnancy factor is immunosuppressive. Nature, Lond. 278, 649-651.

Pfannkoch, E., Lu, K.C. \& Regnier, F.E. (1980) Characterization of some commercial high performance size-exclusion chromatography columns for water-soluble polymers. J. Chromatogr. Sci. 18, 430441.

Radola, B.J. (1974) Isoelectric focusing in layers of granulated gels. II. Preparative isoelectric focusing. Biochim. Biophys. Acta 386, 181-195.

Rolfe, B.E., Morton, H. \& Clarke, F.M. (1983a) Early pregnancy factor is an immunosuppressive contaminant of commercial preparations of human chorionic gonadotrophin. Clin. exp. Immun. 51, 45-52.

Rolfe, B.E., Morton, H., Cavanagh, A.C. \& Gardiner, R.A. (1983b) Detection of an early pregnancy-like substance in sera of patients with testicular germ cell tumors. Am. J. Reprod. Immun. 3, 97-100.

Rolfe, B., Cavanagh, A., Forde, C., Bastin, F., Chen, C. \& Morton, H. (1984) Modified rosette inhibition test using mouse lymphocytes for detection of early pregnancy factor in human pregnancy serum. $J$. immunol. Methods (in press).

Rugh, R. (1968) The Mouse: Its Reproduction and Development, pp. 38-39. Burgess Publishing Company, Minneapolis.

Scopes, R.K. (1974) Measurement of protein by spectrophotometry at $205 \mathrm{~nm}$. Analyt. Biochem. 59, 277-282.

Takagi, T., Takeda, K. \& Okuno, T. (1981) Effect of salt concentration on the elution properties of complexes formed between sodium dodecyl sulphate and protein polypeptides in high-performance silica gel chromatography. J. Chromatog. 208, 201-208.

Wilson, S., McCarthy, R. \& Clarke, F. (1983) In search of early pregnancy factor: isolation of active polypeptides from pregnant ewes sera. J. Reprod. Immun. 5, 275-286.

Received 12 December 1983 